\title{
Biologi reproduksi ikan kembung lelaki, Rastreliger kanagurta (Cuvier, 1816) di perairan pesisir Takalar, Sulawesi Selatan
}

\author{
[Reproductive biology of Indian mackerel, Rastreliger kanagurta (Cuvier, 1816) in Takalar \\ Coastal Waters, South Sulawesi] \\ Mauli Kasmi ${ }^{1}$, Syamsul Hadi ${ }^{1}$, Wayan Kantun ${ }^{2 凶}$ \\ ${ }^{1}$ Politeknik Pertanian Negeri Pangkajene Kepulauan, Jalan Poros Makassar Barru-Mandale Pangkep \\ ${ }^{2}$ Sekolah Tinggi Teknologi Kelautan Balik Diwa, Jalan Perintis Kemerdekaan VIII Nomor 8 Makassar
}

Diterima: 5 Mei 2017; Disetujui: 18 Juli 2017

\begin{abstract}
Abstrak
Penelitian ini bertujuan untuk mengamati biologi reproduksi ikan kembung lelaki di perairan pesisir Takalar melalui perkembangan kematangan gonad, ukuran pertama matang gonad, musim pemijahan, indeks kematangan gonad (IKG), dan fekunditas. Pengambilan sampel dilakukan selama delapan bulan mulai Maret sampai Oktober 2015. Perkembangan kematangan gonad diamati secara morfologi. Musim pemijahan mengacu pada hasil pengamatan langsung terhadap gonad dengan mendata ikan kembung lelaki yang telah memijah. IKG dianalisis berdasarkan perbandingan antara bobot gonad dan bobot tubuh ikan kembung lelaki, sedangkan fekunditas dihitung dengan metode gravimetrik. Hasil analisis menunjukkan bahwa ikan kembung lelaki mengalami kematangan gonad sepanjang tahun dengan puncak terjadi pada bulan Juli dan Agustus. IKG berkisar 0,928-4,490. Ukuran ikan kembung lelaki betina kali pertama matang gonad adalah $21,18 \mathrm{~cm}$ dan jantan adalah $21,31 \mathrm{~cm}$. Pemijahan terjadi setelah puncak kematangan gonad sehingga pada bulan berikutnya terjadi penurunan nilai indeks kematangan secara perlahan dan bertahap. Ikan kembung lelaki memiliki fekunditas total berkisar 11.235-40.878 butir.
\end{abstract}

Kata penting: fekunditas, kematangan gonad, pemijahan, Rastreliger kanagurta

\begin{abstract}
The objective of this research is to observe reproductive biology of Indian mackerel in Takalar coastal waters through gonad maturity development, the first size of mature gonad, spawning, gonado somatic index (GSI), and fecundity. Sampling was done for eight months started from March to October 2015. Gonad maturity stage was observed morphologically, spawning season focusing on direct observation result toward gonad by identifying Indian mackerel which has spawned.GSI was analyzed based on comparison between gonad weight and Indian mackerel weight while fecundity was observed by gravimetric method. Analysis result shows that Indian mackerel gonad maturity throughout the year with peak occurring in July and August. GSI was around 0,928-4,490. The first size of gonad mature of female Indian mackerel is $21,18 \mathrm{~cm}$ and male Indian mackerel is $21,31 \mathrm{~cm}$. Spawning occurs after peak of gonad maturity so next month, value of maturity index decreases slowly and gradually. Indian mackerel has total fecundity around 11.23540.878 granule.
\end{abstract}

Keywords: fecundity, gonad maturity, Rastreliger kanagurta, spawning.

\section{Pendahuluan}

Ikan kembung lelaki (Rastreliger kanagurta) merupakan salah satu ikan pelagis kecil yang banyak ditangkap oleh nelayan di Selat Makassar. Ikan ini ditangkap oleh nelayan dengan menggunakan alat tangkap pancing ulur, jaring insang, dan pukat cincin. Alat tangkap pukat cincin merupakan alat tangkap semi modern yang sampai saat ini hanya sedikit nelayan yang mengoperasikan di Selat Makassar dengan pertimbangan

$\triangle$ Penulis korespondensi

Alamat surel: aryakantun@yahoo.co.id biaya operasional yang terlalu tinggi. Nelayan lebih memilih pancing ulur dan jaring insang yang merupakan alat tangkap tradisional dengan rancangan dan konstruksi yang lebih sederhana. Alat tangkap ini kebanyakan beroperasi di daerah pesisir dan dilakukan oleh nelayan tradisional setiap hari, sehingga ikan kembung bisa ditemukan di pasar dengan ukuran yang tidak bervariasi. Ukuran yang tidak bervariasi tersebut secara biologis menjadi salah satu fenomena dan indikator bahwa sumber daya telah mengalami tekanan penangkapan di alam yang dapat mengancam 
keberlanjutan sumber daya tersebut. Selain itu, produksi ikan kembung lelaki mengalami penurunan dari 23.590,20 ton tahun 2007 menjadi 16.340,65 ton tahun 2014 (Dinas Kelautan dan Perikanan Sulawesi Selatan 2015). Mengacu kepada fenomena variasi ukuran dan penurunan produksi tersebut, maka sangat penting melakukan kajian aspek biologi reproduksi ikan kembung lelaki agar hasilnya dapat dipergunakan sebagai rujukan dasar dalam menentukan kebijakan rencana pengelolaan perikanan tersebut pada masa yang akan datang di daerah ini.

Kajian-kajian sebelumnya telah banyak dilakukan berkaitan dengan ikan kembung lelaki oleh beberapa peneliti. Hariati et al. (2005) mendapatkan ukuran pertama matang gonad untuk jenis kelamin betina dan jantan pada panjang $17,0 \mathrm{~cm}$ di perairan Selat Malaka, Sivadas et al. (2006) memperoleh ukuran pertama matang gonad pada panjang $173 \mathrm{~mm}$ untuk jenis kelamin betina dan jantan di perairan Calicut India, dan Zaki et al. (2016) mendapatkan ukuran pertama matang gonad jantan pada ukuran $252 \mathrm{~mm}$ dan betina pada ukuran $257 \mathrm{~mm}$ di perairan pantai Mahout Laut Arabia. Fekunditas kembung lelaki berkisar 300.000-520.000 butir di perairan utara Aceh (Hariati \& Fauzi 2011) dan berkisar 64.024-151.844 butir di pantai Mahout Laut Arabia (Zaki et al. 2016). Abdussamad et al. (2006) melaporkan bahwa ikan kembung lelaki di perairan Kakinada mempunyai pertumbuhan maksimum sebesar $286 \mathrm{~mm}$, laju pertumbuhan 1,89 per tahun, mortalitas alami 2,61; mortalitas penangkapan 2,08; mortalitas total 4,06; dan potensi lestari 2.239 ton. Zamroni et al. (2008), yang meneliti biologi reproduksi dan genetika populasi ikan kembung lelaki di pantai utara Jawa, mendapatkan nilai indeks kematangan gonad (IKG) ikan kembung lelaki berkisar 0,496,98\%. Oktaviani et al. (2014) meneliti tentang tahapan kematangan gonad ikan kembung lelaki di Teluk Mayalibit Raja Ampat dan mendapatkan sebaran ukuran panjang cagak berkisar 6,3-26,0 $\mathrm{cm}$ dengan memperoleh matang gonad betina sebesar 38,80\% dan matang gonad jantan sebesar 30,70\%. Arrafi et al. (2016) melaporkan puncak pemijahan ikan kembung di perairan Aceh bagian Barat terjadi pada bulan Januari-Maret dan Juli-Oktober, nilai IKG ikan kembung lelaki berkisar 0,32-3,37\%, dan fekunditas berkisar 28.542-123.760 butir. Tamti \& Hasriani (2016) mengemukakan bahwa potensi lestari secara biologis ikan kembung di perairan Selat Makassar sebesar 22 938,08 kg dengan tingkat pemanfaatan telah mencapai $85,59 \%$.

Uraian di atas memperlihatkan bahwa penelitian tentang ikan kembung lelaki telah banyak dilakukan di berbagai tempat, namun belum ada satu penelitian pun yang mengungkapkan tentang aspek reproduksi ikan kembung lelaki di perairan Takalar. Penelitian bertujuan untuk mengamati biologi reproduksi ikan kembung lelaki di perairan pesisir Takalar melalui perkembangan kematangan gonad, ukuran ikan kali pertama matang gonad, musim pemijahan, IKG, dan fekunditas.

\section{Bahan dan metode}

Penelitian ini dilaksanakan selama delapan bulan mulai bulan Maret sampai Oktober 2015 di daerah penangkapan di perairan pesisir Takalar (Gambar 1). Pengambilan sampel dilakukan pada minggu pertama dan ketiga dalam setiap bulan, dengan melakukan pengumpulan data di Tempat Pendaratan Ikan dari kapal yang beroperasi di lokasi penelitian dan tiga kali mengikuti nelayan yakni pada bulan Maret, Juni, dan September untuk menentukan lokasi penangkapan. Alat tangkap yang dipergunakan adalah pancing ulur dengan mata pancing berukuran 10 dan 12 . 
Panjang ikan yang diukur dalam penelitian ini adalah panjang cagak dengan pertimbangan hasilnya lebih akurat dibanding menggunakan panjang total yang terkadang ekornya ada yang rusak. Panjang cagak adalah ukuran panjang ikan mulai dari ujung kepala terdepan sampai ujung bagian luar lekukan cabang sirip ekor. Pengukuran panjang dilakukan menggunakan meteran dengan ketelitian $0,1 \mathrm{~cm}$ terhadap semua hasil tangkapan nelayan yang menangkap pada daerah penelitian. Ikan kembung lelaki dimasukkan ke dalam keranjang untuk dilakukan pengamatan langsung. Bobot ikan (kondisi ikan belum disiangi) ditimbang dengan timbangan digital berketelitian 0,01 gram dan bobot gonad ditimbang dengan timbangan digital dengan ketelitian 0,001 g. Hasil pengukuran panjang dan bobot ikan kembung lelaki akan dihubungkan dengan kematangan gonad ikan sehingga bisa dicari ukuran ikan kali pertama matang gonad dan IKG.
Pengamatan kematangan gonad dan fekunditas dilakukan di Laboratorium Biologi Perikanan, Politeknik Pertanian Negeri Pangkajene Kepulauan. Morfologi perkembangan kematangan gonad ikan kembung lelaki diamati secara makroskopik berdasarkan kriteria pada Tabel 1. Semua sampel dibedah dan diamati.

Ikan yang diamati hanya yang berada pada TKG III sampai V karena gonadnya masih bisa dipisahkan dengan organ lain ketika dibedah. Gonad yang mempunyai TKG I dan II sangat sulit diperoleh utuh, selain kecil juga sering hancur akibat penanganan selama penangkapan. TKG III dan IV digolongkan dalam kategori matang gonad dan TKG V dalam kategori memijah. Ukuran ikan kali pertama matang gonad yang dipergunakan adalah ikan jantan dan betina yang mempunyai TKG III dan IV. Jumlah sampel yang digunakan dalam pengamatan IKG kembung betina

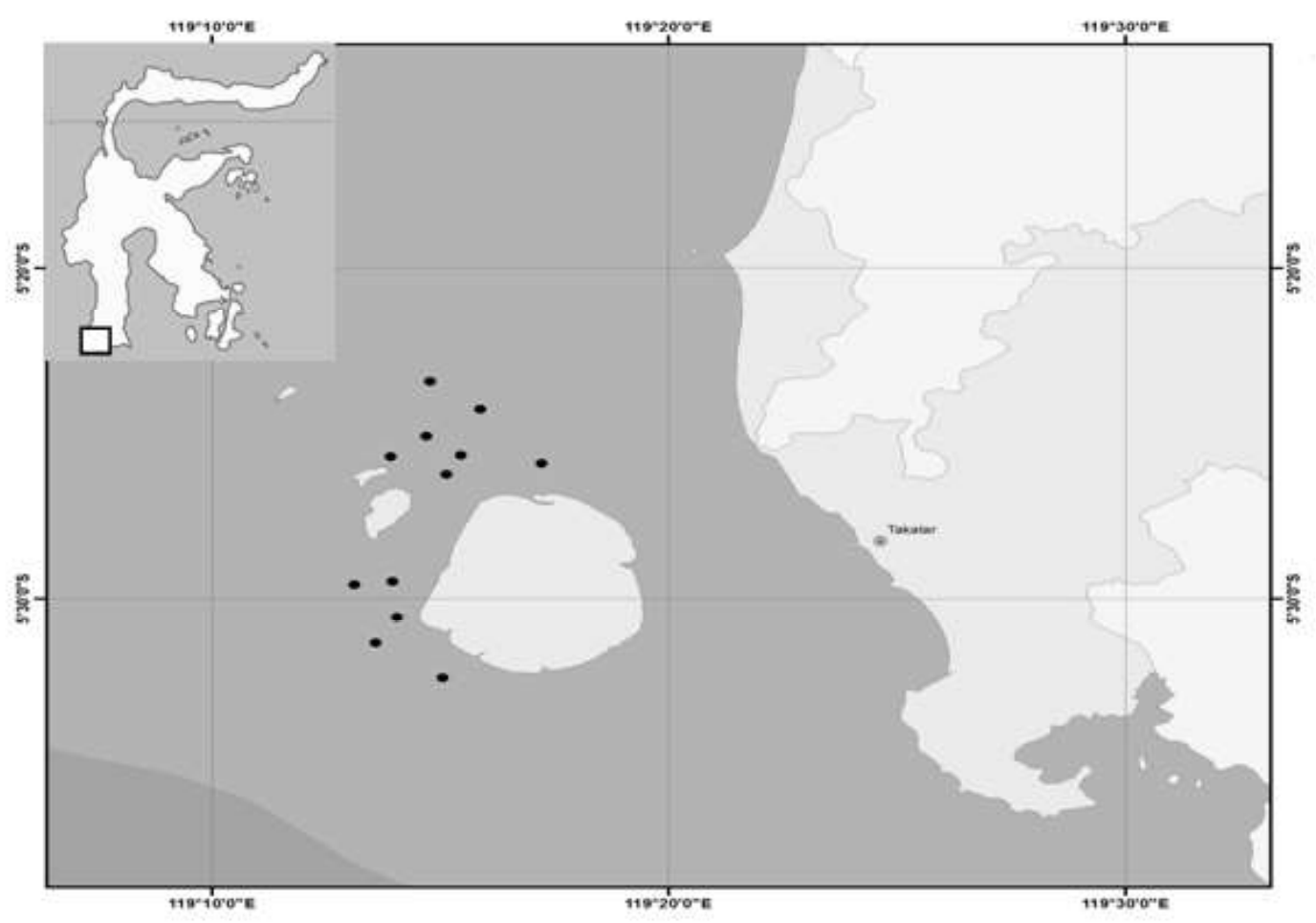

Gambar 1. Lokasi daerah penangkapan kembung lelaki di perairan Pesisir Takalar Sulawesi Selatan 
Tabel 1. Ciri-ciri morfologi kematangan gonad ikan betina dan jantan (Effendie 2002)

\begin{tabular}{|c|c|c|}
\hline $\begin{array}{c}\text { Kematangan } \\
\text { gonad }\end{array}$ & Betina & Jantan \\
\hline $\begin{array}{l}\text { Belum matang } \\
\text { (TKG I) }\end{array}$ & $\begin{array}{l}\text { Ovari berukuran kecil, bisa mencapai } 1 / 2 \text { dari pan- } \\
\text { jang rongga badan. Ovari berwarna kemerahan } \\
\text { jernih. Butiran telur belum tampak. }\end{array}$ & $\begin{array}{l}\text { Testis berukuran kecil, bisa men- } \\
\text { capai } 1 / 2 \text { dari panjang rongga badan } \\
\text { dan berwarna keputih-putihan. }\end{array}$ \\
\hline $\begin{array}{l}\text { Perkembangan } \\
\quad(\mathrm{TKG} \text { II) }\end{array}$ & $\begin{array}{l}\text { Ovari mengisi } 1 / 2 \text { dari panjang ronggabadan. Ovari } \\
\text { berwarna merah orange.Butiran telur belum tampak } \\
\text { jika diamati dengan mata telanjang. }\end{array}$ & $\begin{array}{l}\text { Testis mengisi } 1 / 2 \text { dari panjang } \\
\text { rongga badan dan berwarna putih, } \\
\text { dengan bentuk yang simetris. }\end{array}$ \\
\hline $\begin{array}{c}\text { Pematangan } \\
\text { (TKG III) }\end{array}$ & $\begin{array}{l}\text { Ovari mengisi } 2 / 3 \text { dari panjang rongga badan. Ova- } \\
\text { ri berwarna kuning orange, telah tampak butiran } \\
\text { telur. Pada permukaan ovari telah tampak pembu- } \\
\text { luh darah. Telur masih berwarna gelap dan belum } \\
\text { ada telur-telur yang transparan. }\end{array}$ & $\begin{array}{l}\text { Testis mengisi } 2 / 3 \text { dari panjang } \\
\text { rongga badan dan berwarna putih } \\
\text { kream }\end{array}$ \\
\hline $\begin{array}{l}\text { Matang } \\
(\mathrm{TKG} \text { IV) }\end{array}$ & $\begin{array}{l}\text { Ovari mengisi } 2 / 3 \text { sampai memenuhi rongga badan. } \\
\text { Ovari berwarna orange pink dengan pembuluh- } \\
\text { pembuluh darah tampak dipermukaannya. Telur- } \\
\text { telur terlihat besar, transparan dan matang. }\end{array}$ & $\begin{array}{l}\text { Testis mengisi } 2 / 3 \text { sampai meme- } \\
\text { nuhi rongga badan dan berwarna } \\
\text { putih-kream dengan kondisi lunak. }\end{array}$ \\
\hline $\begin{array}{c}\text { Mijah } \\
(\mathrm{TKG} \mathrm{V)}\end{array}$ & $\begin{array}{l}\text { Ovari menyusut sampai } 1 / 2 \text { dari rongga badan. Din- } \\
\text { ding tebal. Dalam ovari masih tersisa telur-telur } \\
\text { berwarna gelap dan matang yang mengalami disin- } \\
\text { tegrasi akibat penyerapan. }\end{array}$ & $\begin{array}{l}\text { Testis mengalami penyusutan sam- } \\
\text { pai } 1 / 2 \text { dari rongga badan. Kondisi } \\
\text { testis lembek. }\end{array}$ \\
\hline
\end{tabular}

berjumlah 72 ekor dan ikan jantan berjumlah 72 ekor. Sampel untuk keperluan IKG ditentukan secara sengaja dengan pertimbangan keterwakilan dan mengacu pada sampel paling sedikit yang diperoleh dalam setiap bulan serta terkadang ada sampel gonad yang kurang utuh.

Indeks kematangan gonad dihitung dengan menggunakan formula sebagai berikut:

$$
\mathrm{IKG}=\left(\frac{\mathrm{BG}}{\mathrm{BT}}\right)
$$

Keterangan: $\mathrm{IKG}=$ indeks kematangan gonad; $\mathrm{BG}=$ bobot gonad (g); BT = bobot tubuh (g).

Ukuran ikan kali pertama matang gonad dianalisis dengan metode Udupa (1986).

$$
\log m=\mathrm{x}_{\mathrm{k}}+\frac{\mathrm{x}}{2}-\left(\mathrm{x} \times \sum p_{i}\right.
$$

Pada selang kepercayaan 95\% dipergunakan formula:

$$
\text { anti } \log \mathrm{m}=\left(\mathrm{m} \pm 1,96 \sqrt{\mathrm{x}^{2} \times \frac{\mathrm{p}_{i} \times q_{i}}{n_{1}-1}}\right)
$$

Keterangan: Log $m=$ logaritma panjang ikan pada kematangan gonad pertama, $\mathrm{X}_{\mathrm{k}}=$ logaritma nilai tengah pada saat ikan matang gonad $100 \%, \mathrm{X}=$ logaritma pe- nambahan panjang pada nilai tengah, $\mathrm{p}_{\mathrm{i}}=$ jumlah ikan matang gonad pada kelas panjang $\mathrm{ke}-\mathrm{I}, \mathrm{q}_{\mathrm{i}}=1-\mathrm{pi}, \mathrm{n}_{\mathrm{i}}=$ jumlah ikan pada kelas panjang ke-I, $\mathrm{M}=$ panjang ikan pertama kali matang gonad sebesar antilog $\mathrm{m}$.

Ikan yang diamati fekunditasnya adalah ikan kembung lelaki jenis kelamin betina yang berada pada perkembangan kematangan gonad III sampai V. Subsampel yang diambil pada bagian muka (anterior), tengah (median) dan belakang (posterior) kemudian dimasukkan ke dalam botol sampel yang telah berisi larutan Gilson dan direndam selama satu bulan, baru dilakukan penghitungan jumlah telur. Perendaman gonad selama satu bulan dengan pertimbangan telur sudah terpisah dari jaringan ovarium yang menyelimutinya agar lebih mudah menghitungnya.

Sampel untuk pengamatan fekunditas kembung lelaki berjumlah 72 ekor yang mewakili kematangan gonad III, IV, dan V atau setiap bulan diwakili oleh 9 ekor ikan yang masing-masing terdiri atas 3 ekor untuk ke-matangan gonad III, IV dan V. Pengambilan jumlah sampel dilakukan 
secara sengaja dengan pertimbangan telah mewakili untuk dilakukan pengamatan perkembangan kematangan gonad dari belum matang sampai memijah,dan disajikan dalam bentuk grafik atau tabel.

Fekunditas total diestimasi dengan metode gravimetrik (Effendie 1979). Subsampel yang diambil sebanyak 0,01 gram dari total bobot gonad, dengan formula sebagai berikut:

$$
\mathrm{F}=\frac{Q}{q} \times n
$$

Keterangan: $\mathrm{F}=$ fekunditas total (butir), $\mathrm{Q}=$ bobot total $\operatorname{gonad}(\mathrm{g}), \mathrm{q}=$ bobot subsampel $\operatorname{gonad}(\mathrm{g}), \mathrm{n}=$ jumlah telur dalam subsampel gonad (butir).

\section{Hasil}

Sampel yang dikumpulkan berjumlah 934 ekor, yang terdiri atas 405 ekor jenis kelamin betina dan 529 ikan jantan. Ukuran panjang dan bobot ikan betina berkisar 17,3-24,5 cm dan 75,03203,06 gram. Ikan jantan memiliki ukuran panjang dan bobot berkisar 17,1-25,3 cm dan 74,15216,75 gram (Gambar 2).
Perkembangan kematangan gonad ikan kembung lelaki betina dan jantan berdasarkan pengamatan makroskopis terlihat pada Gambar 3. Gambar ini memperlihatkan sebaran ukuran ikan betina fase belum matang berkisar 17,3-20,25 $\mathrm{cm}$, matang pada kisaran 19,5-23,5 cm dan memijah pada kisaran 22,5-24,5 cm (Gambar 3A). Sebaran ukuran ikan jantan untuk fase belum matang berkisar 17,1-20,5 cm, matang pada kisaran 20,0-23,5 cm dan memijah pada kisaran 22,5-25,3 cm (Gambar 3B).

Persentase kematangan gonad ikan kembung lelaki selama penelitian dari tahap belum matang sampai memijah diperlihatkan pada Tabel 2. Pada tabel ini dapat dilihat bahwa kondisi kematangan gonad ikan kembung lelaki betina dan jantan selama penelitian menunjukkan persentase yang hampir sama.

Jumlah ikan berdasarkan perkembangan kematangan gonad menurut waktu pengambilan sampel selama penelitian dapat dilihat pada Gambar 4.

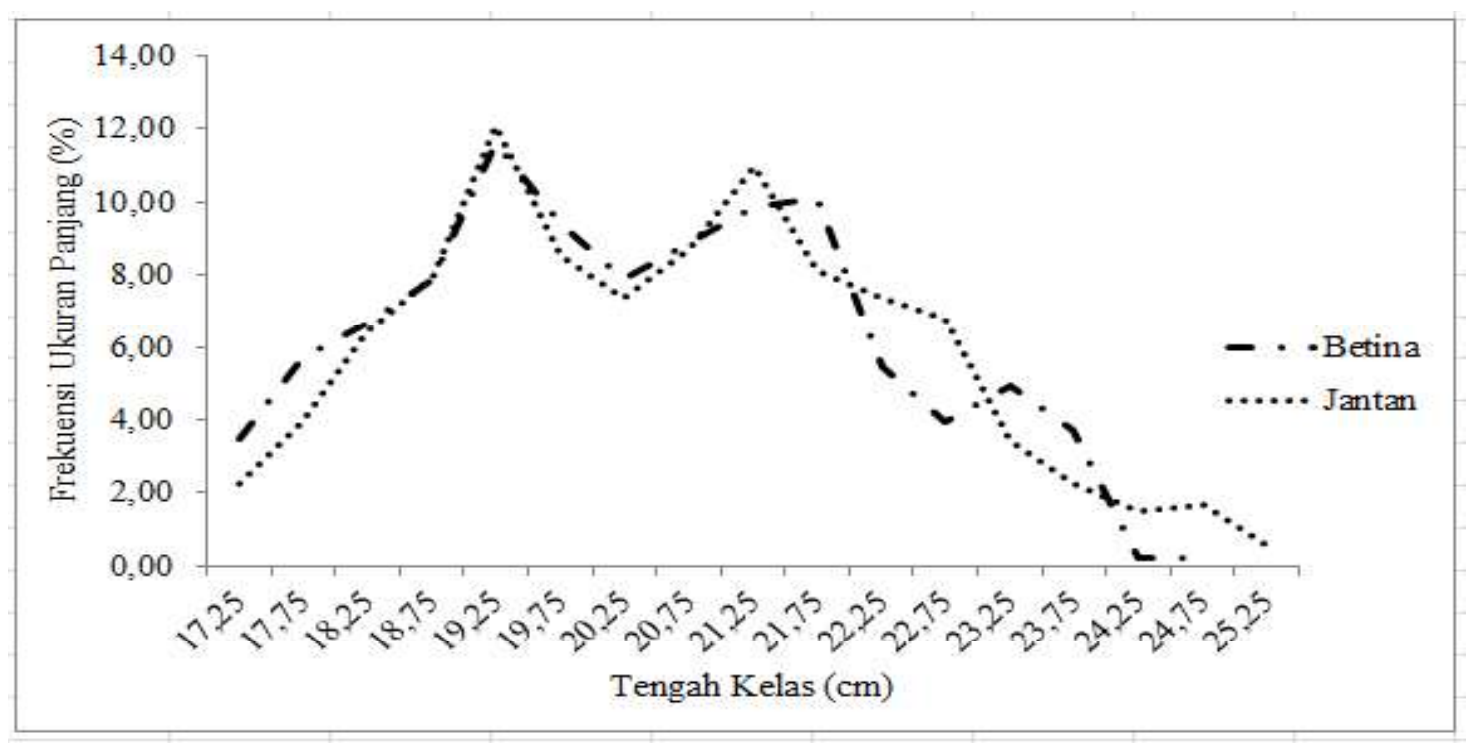

Gambar 2. Sebaran panjang ikan kembung lelaki jenis kelamin betina dan jantan di perairan Pesisir Takalar periode Maret-Oktober 2015. 

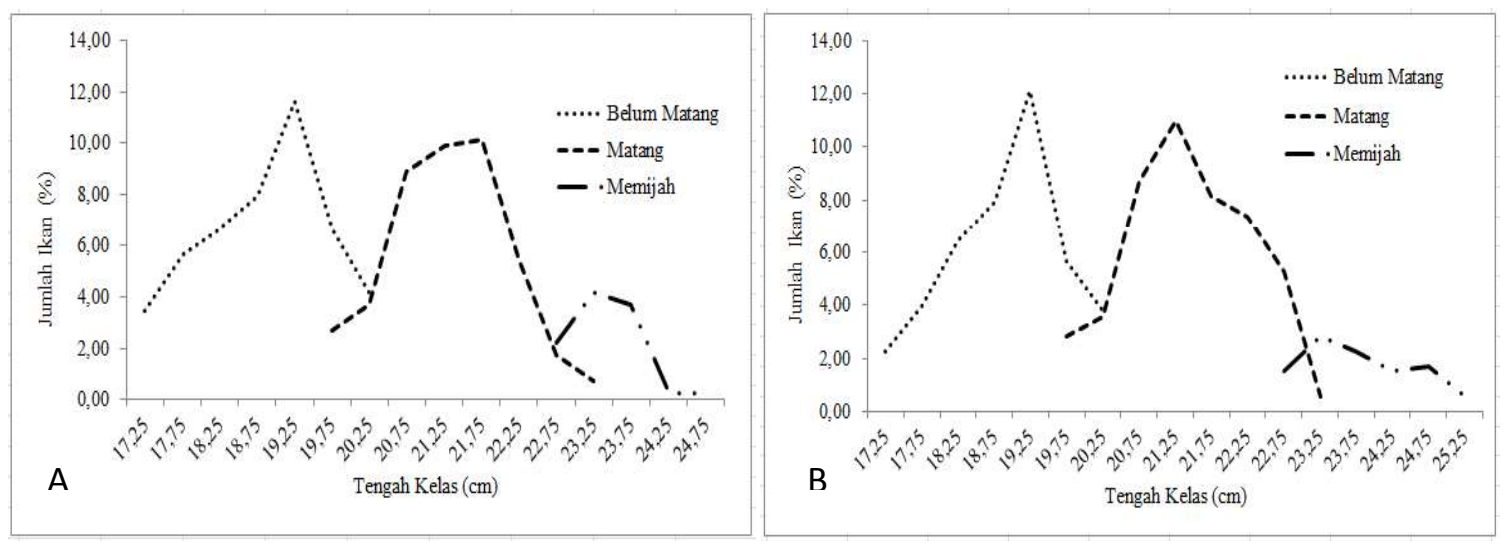

Gambar 3. Sebaran ukuran panjang ikan kembung lelaki jenis kelamin betina (A) dan jantan (B) berdasarkan perkembangan gonad periode Maret-Oktober 2015

Tabel 2. Persentase kematangan gonad ikan kembung lelaki periode Maret-Oktober 2015

\begin{tabular}{lcccc}
\hline \multicolumn{1}{c}{ Kematangan gonad } & \multicolumn{2}{c}{ Betina } & \multicolumn{2}{c}{ Jantan } \\
\hline Belum matang (I-II) & ekor & ekor & 223 & 42,16 \\
Matang gonad (III-IV) & 187 & 46,17 & 251 & 47,45 \\
Memijah (V) & 175 & 43,21 & 55 & 10,40 \\
Total & 43 & 10,62 & 529 & 100 \\
\hline
\end{tabular}
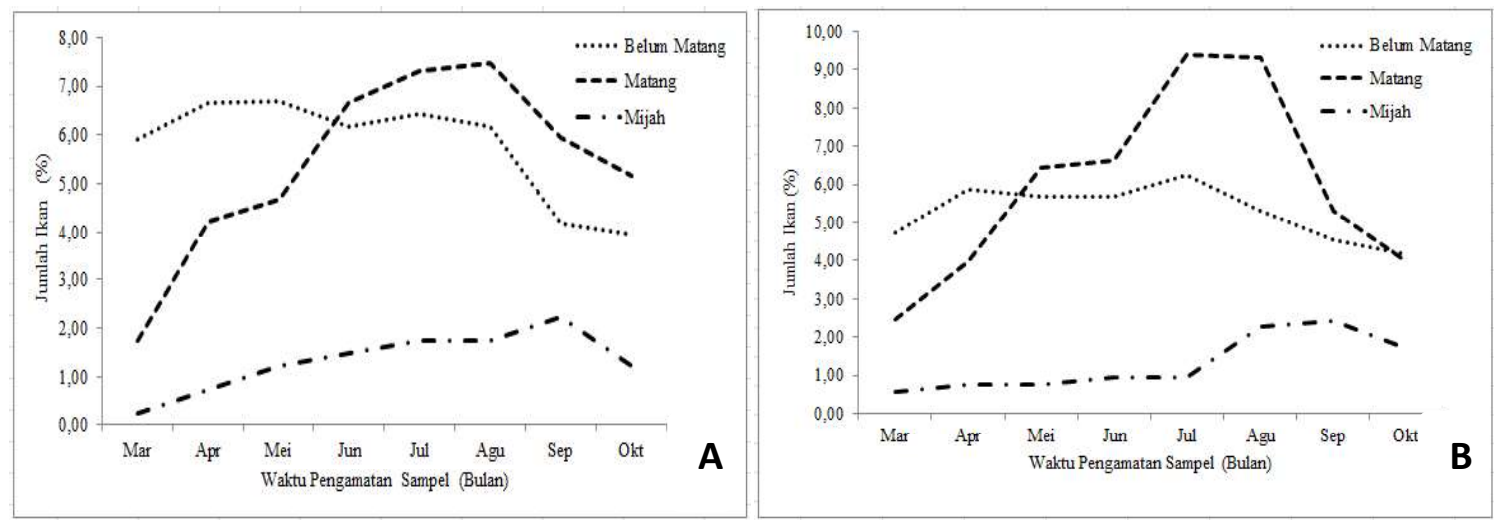

Gambar 4. Persentase jumlah ikan kembung lelaki berdasarkan perkembangan gonad di perairan Pesisir Takalar periode Maret-Oktober 2015. (A) betina dan (B) jantan

IKG ikan betina berkisar 1,29-4,28 dan ikan jantan berkisar 0,93-3,68 (Gambar 5). Ukuran kali pertama ikan kembung lelaki betina matang gonad pada ukuran 21,18 cm dengan tingkat kepercayaan $95 \%$ berkisar 21,06-21,31 cm dan ikan jantan pada ukuran 21,31 cm berkisar 21,2321,39 cm (Gambar 6).

Fekunditas total ikan kembung lelaki jenis kelamin betina yang diperoleh selama penelitian berkisar 11.235-40.878 butir. 


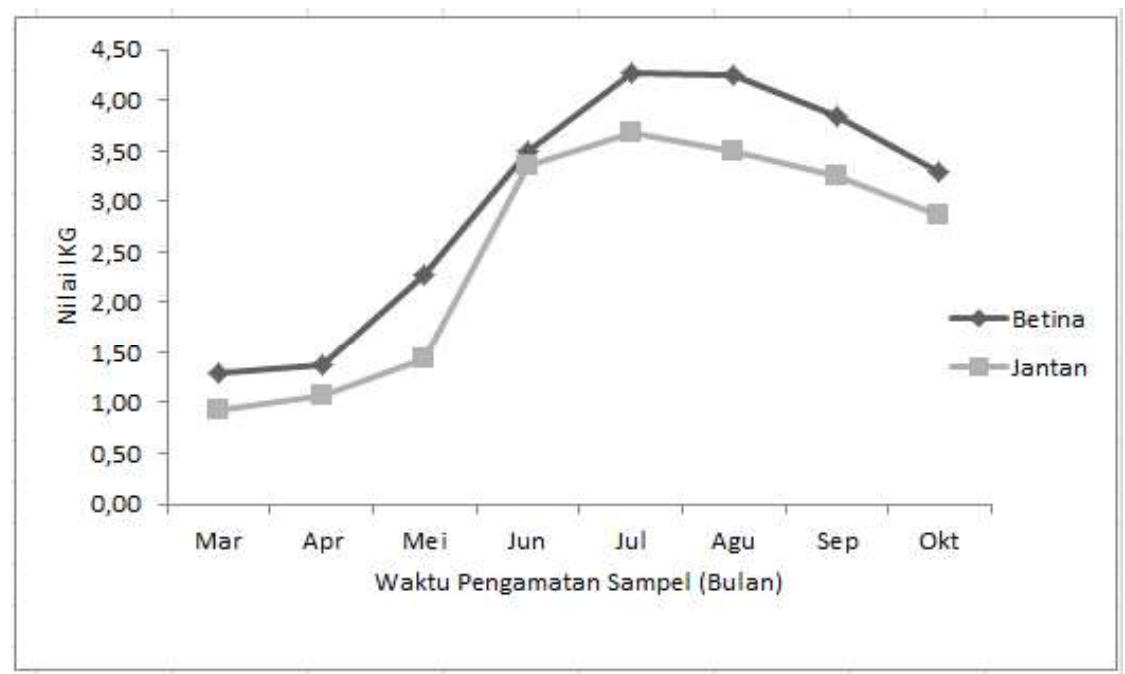

Gambar 5. Perkembangan IKG kembung lelaki di perairan Pesisir Takalar periode Maret-Oktober 2015
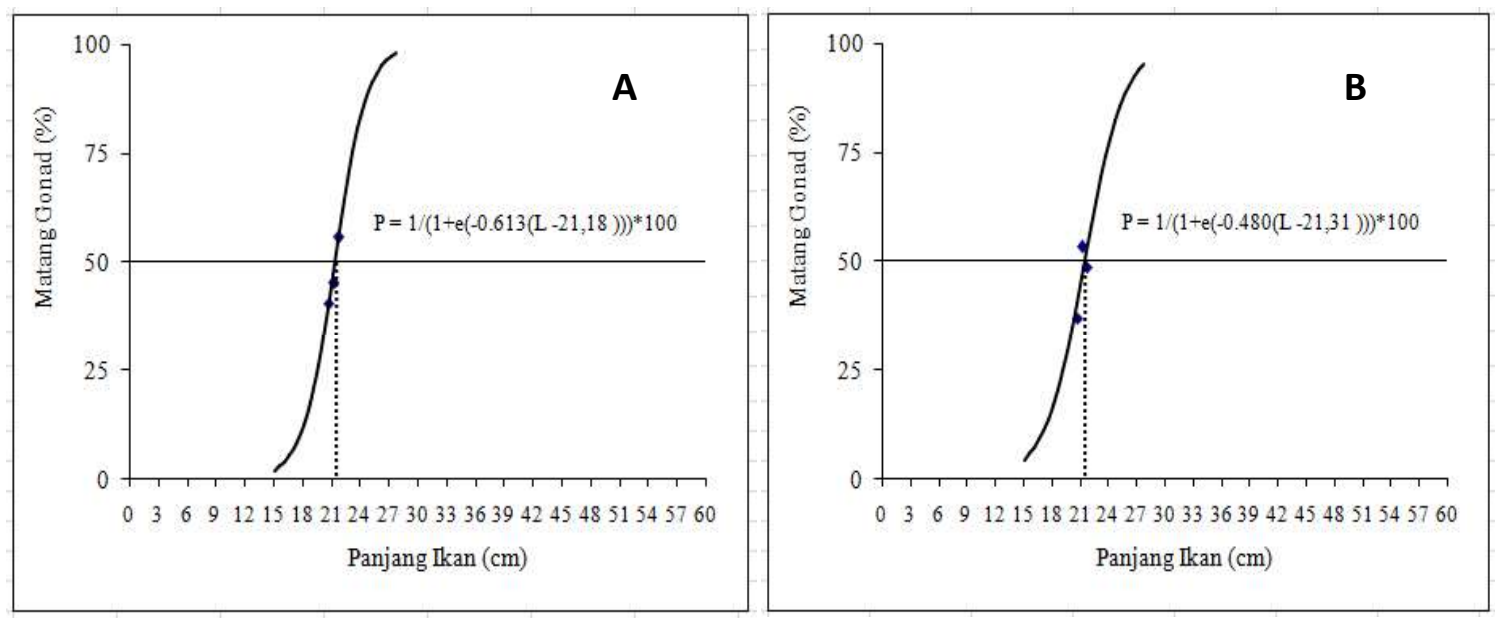

Gambar 6. Ukuran pertama matang gonad ikan kembung lelaki jenis kelamin betina (A) dan jantan (B) di perairan Pesisir Takalar periode Maret-Oktober 2015.

\section{Pembahasan}

Secara umum pada penelitian ini diperoleh ukuran panjang berkisar 17,1-25,3 cm (Gambar 2) dan bobot berkisar 74,15-216,75 gram. Kisaran ukuran ini lebih sempit dibanding yang diperoleh Arrafi et al. (2016) yang berkisar 7-26 cm dan Oktaviani et al. (2014) yang mendapatkan sebaran ukuran pada panjang cagak berkisar 6,3$26,0 \mathrm{~cm}$. Sebaran ukuran sangat dipengaruhi oleh alat tangkap yang digunakan. Peneliti terdahulu menggunakan jaring berukuran $0,5 \mathrm{~cm}$ sehingga ikan yang tertangkap mulai dari ukuran kecil sampai besar. Penelitian ini menggunakan pancing berukuran 10 dan 12 sehingga ikan yang tertangkap pada umumnya berukuran besar. Ukuran mata pancing yang berbeda dapat menyebabkan perbedaan fisik setiap ukuran mata pancing. Erzini et. al (1998) berpendapat bahwa jumlah dan komposisi jenis hasil tangkapan pada perikanan pancing dapat dipengaruhi oleh dua faktor penting yaitu tipe dan ukuran mata pancing. Sementara itu, Rahmat (2007) mengatakan bahwa perbedaan fisik tiap ukuran mata pancing dapat memengaruhi bobot maupun jumlah tiap jenis tangkapan pada perikanan pancing. Ukuran mata pancing dapat memengaruhi komposisi ukuran ikan yang tertangkap dari segi bobot dan panjang. Pada bagian lain, Kantun et al. (2014a) 
menyatakan bahwa metode penangkapan yang berhubungan dengan perbedaan waktu penangkapan, waktu makan ikan, jenis umpan dan posisi kedalaman pengoperasian pancing berkontribusi terhadap ukuran ikan yang tertangkap.

Bervariasinya ukuran ikan yang tertangkap juga disebabkan oleh sifat biologi ikan yang terkait dengan tingkah laku bergerombol ikan, yang umumnya akan bergerombol dengan ukuran yang sama dan jenis yang sama. Hal ini senada dengan yang diungkapkan oleh Soria \& Dagorn (1992) yang menyatakan bahwa ikan yang bergerombol merupakan sekumpulan individu dengan ukuran, siklus biologi dan kemampuan biologi yang sama, dipersatukan oleh kerjasama yang saling menguntungkan dan menunjukkan kemampuan dalam melakukan koordinasi ketika berenang dalam suatu kelompok. Pada sisi lain, kemampuan ikan berkoordinasi ini merupakan ciri khas populasi ikan dewasa yang suka hidup bergerombol dan bergerak cepat secara bersamaan dan beriringan (Dewanti et al. 2014).

Perkembangan kematangan gonad ikan kembung lelaki, secara umum memperlihatkan bahwa jumlah ikan betina belum matang gonad lebih besar daripada jantan $(46,17 \%>42,16 \%)$, betina matang gonad lebih kecil daripada jantan $(43,21 \%<47,45 \%)$, dan betina memijah lebih besar daripada jantan $(10,62 \%>10,40 \%)$. Hasil penelitian Oktaviani (2014) yang dilakukan di Teluk Mayalibit Papua Barat memperoleh ikan betina matang gonad sebesar $38,80 \%$ dan jantan matang gonad sebesar $30,70 \%$. Hasil penelitian ini memiliki komposisi perkembangan kematangan gonad dalam kondisi matang lebih besar dibanding peneliti sebelumnya. Hal ini disebabkan oleh perkembangan kematangan gonad ikan kembung lelaki yang tidak sama (Gambar 4) berdasarkan waktu pengamatan karena adanya kelompok ikan yang memijah tidak bersamaan.
Brojo \& Sari (2002) menyatakan bahwa ketidakseragaman perkembangan gonad pada ikan disebabkan adanya kelompok ikan yang pemijahannya berbeda. Sementara itu, Paugy (2002) dan Lalèyè et al. (2006) menyatakan bahwa perkembangan kematangan gonad ikan bisa berbeda disebabkan oleh sifat genetik populasi, perbedaan laju pertumbuhan dan kualitas perairan, sedangkan Reynolds et al.(2001) dan de Graaf et al. (2003) berpendapat bahwa perbedaan perkembangan gonad ikan bisa disebabkan oleh perbedaan wilayah dan tekanan penang-kapan.

Nilai IKG ikan kembung lelaki betina lebih besar dibanding ikan jantan (Gambar 5) disebabkan bobot gonad ikan betina lebih besar daripada bobot gonad ikan jantan. Hasil penelitian Zamroni et al. (2008) di pantai utara Jawa mendapatkan IKG ikan kembung lelaki berkisar 0,49-6,98. Arrafi et al. (2016) menemukan nilai IKG ikan kembung lelaki di perairan bagian barat Aceh berkisar 0,32-3,37\%. Tinggi rendahnya nilai IKG ikan kembung lelaki disebabkan oleh faktor lingkungan yang berhubungan langsung dengan ketersediaan makanan sebagai sumber energi untuk perkembangan somatik dan reproduksinya. Siby et al. (2009) menyatakan bahwa nilai rata-rata IKG ikan betina selalu lebih besar daripada IKG ikan jantan pada TKG yang sama. Hal ini disebabkan pertambahan bobot ovarium selalu lebih besar daripada pertambahan bobot testis. Peningkatan bobot ovarium berhubungan dengan proses vitellogenesis dalam perkembangan gonad, sedangkan peningkatan bobot testis berhubungan dengan proses spermatogenesis dan peningkatan volume semen dalam tubulus seminiferi.

Peningkatan nilai IKG ikan merupakan salah satu indikator musim pemijahan. Berdasarkan nilai IKG setiap bulan, puncak pemijahan ikan kembung lelaki betina dan jantan terjadi sesaat setelah nilai IKG tertinggi. Hal ini sejalan dengan 
pendapat Araffi et al. (2014) bahwa nilai IKG yang tinggi menjadi indikasi musim pemijahan. Pemijahan biasanya terjadi setelah puncak-puncak kematangan gonad, sehingga pada tahapan berikutnya terjadi penurunan IKG. Proses penurunannya berlangsung dengan cepat, seperti terlihat pada Gambar 5, yakni terjadi pada bulan September dan Oktober. Hal senada diungkapkan oleh Effendie (1992) bahwa bobot gonad akan mencapai maksimum sesaat ikan akan memijah kemudian bobot gonad akan menurun dengan cepat selama pemijahan sedang berlangsung sampai selesai.

Ukuran ikan kali pertama matang gonad sangat terkait dengan kematangan gonad dan IKG. Ukuran kali pertama matang gonad yang diperoleh setiap peneliti berbeda-beda seperti tersaji pada Tabel 4. Ukuran kali pertama matang gonad ikan kembung lelaki pada penelitian ini lebih kecil dibanding penelitian di pantai Mahout laut Arabia oleh Zaki et al. (2016) dan lebih besar daripada beberapa peneliti terdahulu lainnya. Besar kecilnya ukuran kali pertama ikan matang gonad disebabkan oleh faktor spesies, lingkungan, umur, ukuran, dan kondisi fisiologis ikan (Udupa 1986). Koido \& Suzuki (1989) dan Schaefer (1987) berpendapat bahwa periode pengambilan sampel dan musim reproduksi ikan yang berbeda dari masing-masing daerah penelitian dilakukan. Kantun et al. (2014b) mengemukakan bahwa aktifitas penangkapan terkait metode penangkapan dan jenis alat tangkap yang digunakan akan membatasi ukuran ikan yang tertangkap sehingga dapat menyebabkan perbedaan ukuran ikan kali pertama matang gonad ketika dianalisis. Selanjutnya Kantun et al. (2015) menyatakan bahwa besar kecilnya ukuran matang gonad ikan yang tertangkap dari setiap lokasi penelitian disebabkan pada tempat pengambilan sampel telah terjadi tangkap lebih, sehingga yang tertangkap ikan yang berukuran kecil-kecil namun telah matang gonad. Siby et al. (2009) berpendapat bahwa ukuran kali pertama matang gonad pada ikan yang berbeda-beda dan terjadi pada ukuran yang lebih kecil merupakan taktik reproduksi ikan untuk memulihkan keseimbangan populasinya yang disebabkan oleh perubahan kondisi, faktor abiotik, dan tangkap lebih. Rahardjo \& Charles (2007) menyatakan bahwa beberapa faktor yang dapat menyebabkan bervariasinya ukuran kali pertama matang gonad yaitu sifat genetik populasi, perbedaan letak wilayah, kualitas perairan, dan besarnya tekanan penangkapan.

Ketersediaan dan keberlanjutan sumber daya ikan kembung lelaki di perairan pesisir Takalar dapat dijaga dengan menangkap pada ukuran

Tabel 4. Ukuran kali pertama matang gonad ikan kembung lelaki pada beberapa lokasi

\begin{tabular}{|c|c|c|c|c|}
\hline \multirow[b]{2}{*}{ Lokasi } & \multicolumn{2}{|c|}{ Jenis kelamin } & \multirow{2}{*}{$\begin{array}{l}\text { Ukuran ikan pertama } \\
\text { matang gonad }(\mathrm{cm})\end{array}$} & \multirow[b]{2}{*}{ Sumber } \\
\hline & $q$ & $\hat{\sigma}$ & & \\
\hline Selat Malaka & \multicolumn{2}{|c|}{ q0 } & 17,0 & Hariati et al. (2005) \\
\hline Calicut India & \multicolumn{2}{|c|}{ +क人 } & 17,3 & Sivadaset al.(2006) \\
\hline Pantai utara Aceh & 우 & - & 19,97 & Hariati \& Fauzi (2011) \\
\hline Mangalore, India & 우 & & 21,0 & Hulkoti et al. (2013) \\
\hline Pantai Mahout laut Arabia & 우 & $\hat{\sigma}$ & q 25,7; Љ 25,2 & Zaki et al. (2016) \\
\hline Perairan bagian barat Aceh & q & - & 19,58 & Arrafi et al. (2016) \\
\hline Perairan pesisir Takalar & q & $\hat{\sigma}$ & ㅇ 21,$18 ; \Uparrow 21,31$ & Penelitian ini \\
\hline
\end{tabular}


minimal di atas ukuran kali pertama matang gonad, yakni di atas 21,18 cm untuk jenis kelamin betina dan di atas 21,31 cm untuk jenis kelamin jantan. Hal ini dilakukan dengan pertimbangan memberikan kesempatan kepada ikan kembung lelaki untuk melakukan reproduksi terlebih dahulu dalam menjaga eksistensinya. Kantun et al (2015) berpendapat bahwa semakin banyak ikan yang tertangkap di atas ukuran kali pertama matang gonad, maka peluang untuk menjaga eksistensinya semakin besar. Oleh sebab itu sangat penting dalam melakukan pengelolaan memperhatikan aspek biologi reproduksi ikan agar keberlanjutan sumber daya ikan kembung lelaki dapat terjamin.

Ikan kembung lelaki yang tertangkap dalam kondisi mijah berkisar 10,40-10,62\% tergolong masih sangat rendah (Tabel 2), karena ikan sedang dalam proses pematangan gonad yang akan mencapai puncaknya pada bulan Juli dan Agustus (Gambar 5) dan diduga pada bulan September terjadi pemijahan. Kejadian ini juga bisa dilihat dari nilai IKG yang secara individual akan mencapai puncak tertingginya ketika mencapai fase kematangan gonad IV dan selanjutnya akan menurun secara perlahan setelah melakukan pemijahan. Setelah memijah gonad ikan tidak langsung kempis, tetapi akan mengempis secara perlahan-lahan. Cara pemijahan yang sama juga ditemukan oleh Oktaviani et al, (2014) di Teluk Mayalibit yang menemukan puncak pemijahan ikan kembung lelaki pada bulan September November dengan periode penelitian berbeda dari penelitian ini. Zaki et al. (2016) menemukan dua puncak pemijahan di pantai Mahout laut Arabia yaitu pada bulan September-Oktober dan Desember-April. Arrafi et al.(2016) juga menemukan dua puncak pemijahan di perairan bagian barat Aceh yakni pada bulan Januari-Maret dan Juli-Oktober. Sementara itu Koido \& Suzuki
(1989) dan Schaefer (1987) menyatakan menemukan periode pemijahan yang berbeda-beda pada setiap lokasi penelitian disebabkan periode sampling, kondisi lingkungan terkait ketersediaan makanan, dan aktifitas penangkapan. Pola pemijahan seperti ini sangat memungkinkan ikan kembung lelaki selalu tersedia di alam, sepanjang pengelolaannya mengacu kepada aspek reproduksinya, seperti menangkap pada ukuran di atas ukuran kali pertama matang gonad. Abdussamad et al. (2010) menyatakan bahwa fase perkembangan kematangan gonad terjadi sepanjang tahun dan mengasumsikan ikan memijah sepanjang tahun.

Fekunditas ikan kembung lelaki berkisar berkisar 11.235-40.878 butir. Hasil penelitian sebelumnya seperti yang dilakukan oleh Hariati \& Fauzi (2011) di pantai utara Aceh memperoleh fekunditas berkisar 300.000-520.000 butir. Zaki et al. (2016) di pantai Mahout laut Arabia mendapatkan fekunditas berkisar 64.024-151.844 butir dan Arrafi et al. (2016) di perairan bagian barat Aceh memperoleh fekunditas berkisar 28.542-123.760 butir. Hulkoti et al. (2013) memperoleh fekunditas berkisar 86.744-94.376 butir. Jumlah fekunditas pada penelitian ini lebih kecil dibanding peneliti-peneliti yang lain. Besar kecilnya fekunditas suatu spesies dipengaruhi oleh beberapa faktor, antara lain ukuran panjang dan bobot ikan (Vila-Gispert \& Moreno-Amich 2000), ukuran diameter telur (Suzuki et al. 2000) dan faktor lingkungan (Abidin 1986). Hal senada diungkapkan oleh Rochmatin et al. (2014) bahwa beberapa faktor yang berperan terhadap jumlah telur yang dihasilkan oleh ikan betina yaitu fertilitas, frekuensi pemijahan, perlindungan induk, ukuran telur, kondisi lingkungan, dan ke-padatan populasi. Sementara itu, Siby et al. (2009) menyatakan bahwa fekunditas yang berbeda-beda diantara spesies merefleksikan strategi repro- 
duksinya. Bahkan dalam spesies, fekunditas bervariasi sebagai hasil dari perbedaan adaptasi ikan terhadap lingkungannya. Ikan yang berukuran besar menghasilkan fekunditas yang besar. Pada ukuran yang sama, ikan betina dalam kondisi yang baik menghasil-kan fekunditas yang lebih tinggi.

Mengacu pada jumlah fekunditas yang dihasilkan, ikan kembung lelaki betina menunjukkan tingkat produktivitas yang tinggi. Hal ini didasari atas pendapat Musick (2000) bahwa tingkat produktivitas ikan berdasarkan indeks reproduksi dengan parameter fekunditas. Jika fekunditas kurang dari 10 butir tergolong sangat rendah, 10100 butir termasuk rendah, 100-1000 butir tergolong sedang, dan di atas 1000 butir tergolong tinggi. Musick (2000) juga menyatakan bahwa fekunditas bisa dijadikan indikator produktivitas suatu organisme yang ditunjang oleh faktor lingkungan, genetika, pertumbuhan, umur dan kematangan gonad.

\section{Simpulan}

Perkembangan kematangan gonad ikan kembung lelaki di perairan pesisir Takalar diperoleh mulai ukuran belum matang sampai memijah, yang mengindikasikan bahwa perkembangan kematangan gonad tidak sama dan adanya kelompok ikan yang memijah tidak bersamaan. Nilai IKG yang bervariasi disebabkan oleh faktor lingkungan yang berhubungan langsung dengan ketersediaan makanan sebagai sumber energi untuk perkembangan somatik dan reproduksinya.

Ukuran kali pertama matang gonad pada ikan disebabkan oleh perubahan kondisi lingkungan, faktor abiotik, genetik populasi, perbedaan letak wilayah, kualitas perairan, dan besarnya tekanan penangkapan. Fekunditas dipengaruhi oleh ukuran panjang dan bobot ikan, diameter telur, fertilitas, frekuensi pemijahan, ukuran telur, kondisi lingkungan, dan kepadatan populasi.

Keberlanjutan sumber daya ikan kembung lelaki di perairan pesisir Takalar dapat dijaga dengan menangkap pada ukuran minimal di atas ukuran kali pertama matang gonad, yakni di atas $21,18 \mathrm{~cm}$ untuk jenis kelamin betina dan di atas 21,31 cm untuk jenis kelamin jantan.

\section{Persantunan}

Terima kasih disampaikan kepada Kemenristek Dikti atas bantuan pendanaan melalui hibah Penelitian Strategis Nasional dan terima kasih kepada tim peneliti dan nelayan yang terlibat dalam penelitian ini. Terima kasih juga disampaikan kepada bebestari atas saran dan koreksiannya sehingga artikel ini menjadi lebih berkualitas.

\section{Daftar pustaka}

Abdussamad EM, Kasim HM, Achayya P. 2006. Fishery and population characteristics of Indian mackerel, Rastrelliger kanagurta (Cuvier) at Kakinada. Indian Journal of Fisheries, 53(1): 77-83.

Abidin AZ. 1986. The reproductive biology of a tropical cyprinid Hampalamacrolepidota from Negara Zoo Lake, Kuala Lumpur, Malaysia. Journal of Fish Biology, 29(3): 381-391

Arrafi M, Ambak A, Rumeaida P, Muchlisin ZA. 2016.Biology of Indian mackerel, Rastrelliger kanagurta (Cuvier,1817) in the Western Waters of Aceh. Iranian Journal of Fisheries Sciences, 15(3): 957-972.

Brojo M, Sari RP. 2002. Biologi reproduksi ikan kurisi (Nemipterus tambuloides Blkr.) yang didaratkan di Tempat Pelelangan Ikan Labu an, Pandeglang. Jurnal Iktiologi Indonesia. 2(1): $9-13$

De Graaf M, Machiels M, Wudneh T, Sibbing FA. 2003. Length at maturity and gillnet selectivity of Lake Tana's Barbus species (Ethiopia): Implications for management and conservation. Aquatic Ecosystem Health \& Management, 6(3): 325-336

Dewanti RON, Ghofar A, Saputra SW. 2014. Beberapa aspek biologi ikan teri (Stole-phorus 
devisi) yang tertangkap payang di perairan Kabupaten Pemalang. Diponegoro Journal of Maquares, 3(4): 102-111.

Dinas Perikanan dan Kelautan Sulawesi Selatan. 2015. Data Statistik Perikanan Provinsi Sulawesi Selatan.

Effendie M I. 1979. Metoda Biologi Perikanan. Yayasan Dewi Sri. Bogor. 112 hlm

Effendie M I. 2002. Biologi Perikanan. Yayasan Pustaka Nusatama. Yogyakarta.163 hlm.

Erzini K, Goncalves JMS, Bentes L, Lino PG, Ribeiro J. 1998. Species and size selec-tivity in a 'red' sea bream longline 'me-tier' in the Algarve (southern Portugal). Aquatic Living Resources, 11(1): 1-11.

Hariati T, Taufik M, Zamroni A. 2005. Beberapa aspek reproduksi ikan layang (Decapterus russelli) dan ikan banyar (Rastrelliger kanagurta) di perairan Selat Malaka Indonesia. Jurnal Penelitian Perikanan Indonesia edisi sumber daya dan Penangkapan, 11(2): 4757.

Hariati T, Fauzi M. 2011. Aspek reproduksi ikan banyar, Rastreliger kanagurta (Cuv. 1817) di perairan utara Aceh. Jurnal Iktiologi Indonesia, 11(1): 47-53.

Hulkoti SH, Shivaprakash SM, Anjanayappa HN, Somashekara SR, Benakappa S, Naik ASK, Kumar J. 2013. Breeding biology of Indian mackerel, Rastrelliger kanagurta (Cuvier) from Mangalore Region. Environment and Ecology, 31(2A): 683-688.

Kantun W, Achmar M, Nuraeni LR. 2014a. Struktur ukuran dan jumlah tangkapan tuna madidihang menurut waktu penangkapan dan kedalaman di perairan Majene Selat Makassar. Indonesian Journal of Fisheries Science and Technology, 9(2): 39-48.

Kantun W, Achmar M, Nuraeni LR. 2014b. Perbandingan struktur ukuran tuna madidihang Thunnus albacares yang tertangkap pada rumpon laut dalam dan laut dangkal di perairan Selat makassar. Jurnal Ipteks Pemanfaatan Sumberdaya Perikanan, 1(2): 112128.

Kantun W, Syamsu AA, Achmar M, Ambo T. 2015. Potensi reproduksi tuna madidihang Thunnus albacares di Selat Makassar. In: Zainuddin IM (Editor). Prosiding Simposium Nasional Pengelolaan Perikanan Tuna Berkelanjutan. Bali 10-11 Desember 2014.
II-142. World Wildlife Foundation -Indonesia. 1259 p.

Koido T. Suzuki Z. 1989. Main spawning season of yellowfin tuna, Thunnus albacares, in the western tropical Pacific Ocean based on the gonad index. Bulletin Far Seas Fisheries Research Laboratory, 26(2): 153-164.

Lalèyè $\mathrm{P}$, Chikou $\mathrm{A}$, Gnohossou $\mathrm{P}$, van Dewalle P, Philippart JC, Teugels G. 2006. Studies on the biology of two species of catfish Synodontis schall and Synodontis nigrita (Ostariophysi: Mochokidae) from the Ouémé River, Bénin. Belgium Journal of Zoology, 136(2): 193-201

Musick JA. 2000. Ecology and conservation of long-lived marine animals. In Musick JA. (Editor). Life in the slow lane: Symposium on the Ecology and Conservation of LongLived Marine Animals. American Fisheries Society. $265 \mathrm{p}$.

Oktaviani D, Supriatna J, Erdmann MV, Abinawanto. 2014. Maturity stage of Indian mackerel Rastreliger kanagurta (Cuvier, 1816) in Mayalibit Bay, Raja Ampat, West Papua. International Journal of Aquatic Science, 5(1): 67-76.

Paugy D. 2002. Reproductive strategies of fishes in a tropical temporary stream of the Upper Senegal basin: Baoulé River in Mali. Aquatic Living Resources, 15(1): 25-35

Rahardjo MF, Charles PHS. 2007. Aspek reproduksi ikan tetet Johnius belangerii Cuvier (Pisces Sciaenidae) di perairan Pantai Mayangan Jawa Barat. Jurnal Perikanan 9(2): 200-207.

Rahmat E. 2007. Penggunaan pancing ulur (hand line) untuk menangkap ikan pelagis besar di perairan Bacan, Halmahera Selatan. Jurnal Penelitian Perikanan Laut, 6(1): 29-33.

Reynolds JD, Jennings S, Dulvy NK. 2001. Life histories of fishes and population responses to exploitation. In: Reynolds JD, Mace GM, Redford KH, Robinson JG (Eds.). Conservation of Exploited Species. Cambridge University Press, Cambridge. pp. 148-168.

Rochmatin SY, Anhar S, Suradi WS. 2014. Aspek pertumbuhan dan reproduksi ikan nilem (Osteochilus hasselti) di perairan Rawa Pening Kecamatan Tuntang Kabupaten Semarang. Journal of Maquares, 3(3): 153-159.

Schaefer KM. 1987. Reproductive biology of black skipjack, Euthynnus lineatus, an 
eastern Pacific tuna. Inter-American Tropical Tuna Comission. 19 (2): 166-260.

Siby LS, Rahardjo MF, Sjafei DS. 2009. Biologi reproduksi ikan pelangi merah (Glossolepis incisus, Weber 1907) di Danau Sentani. Jurnal Iktiologi Indonesia, 9(1): 49-61.

Sivadas M, Radhakrishnan PN, Balasubramanian KK, Bhaskaran MM. 2006. Lengthweight relationship, relative condition, size at first maturity, and sex ratio of Indian mackerel Rastrelliger kanagurta from Calicut. Journal of the Marine Biological Association of India, 48 (2): 274-277.

Soria M, Dagom L. 1992. Rappels surle comportement grégaire. in: Action Incitative Comportement Agrégatif (AICA), CompteRendu de Réunion, Doc. Centre ORSTOM Montpellier, 9: 5-9

Suzuki HI, Agostinho AA, Winemiller KO. 2000. Relationship between oocyte morphology and reproductive strategy in lori-cariid catfishes of the Paraná River, Brazil. Journal of Fish Biology, 57(3): 791-807
Tamti H, Hasriani H. 2016. Analisis bioekonomi ikan kembung Rastreliger spp. di perairan Selat Makassar. Jurnal Balik Diwa, 7(2): 714.

Udupa KS. 1986. Statistical method of estimating the size at first maturity in fishes. Fishbyte, 4(2): 8-10.

Vila-Gispert A, Moreno-Amich R. 2000. Fecundity and spawning mode of three introduced fish species in Lake Banyoles (Catalunya, Spain) in comparison with other localities. Aquatic Sciences, 62(2): 154-166

Zamroni A,Suwarso, Mukhlis NA. 2008. Biologi reproduksi dan genetik populasi ikan kembung (Rastrelliger kanagurta, Famili Scombridae) di Pantai Utara Jawa. Jurnal Penelitian Perikanan Indonesia, 14(2): 215-226.

Zaki S, Jayabalan N, Al-kiyumi F, Al-kharusiL. 2016. Reproductive biology of the Indian mackerel Rastrelliger kanagurta (Cuvier, 1816) from the Mahout coast, Sultanate of Oman. Indian Journal of Fisheries, 63(2): 24-32. 